\title{
THE CONFUSION OF MARXIAN AND FREUDIAN FETISHISM IN ADORNO AND BENJAMIN \\ Donovan Mioyasaki
}

Both Theodor Adorno and Walter Benjamin borrow from Freudian theory in their analyses of fetishism's relation to the contemporary reception of cultural products. I will argue that both authors have confused the Marxian and Freudian theories of fetishism, resulting in mistaken conclusions about artistic reception. By disentangling the Marxian and Freudian elements in both authors' positions, I want to show that 1) Adorno's characterization of regressive listening implies, contrary to his intentions, that the current reception of artwork is in fact antagonistic to fetishism, and that 2) his criticism of Benjamin's optimism toward "reception in distraction" is nevertheless justified. If I am correct, it may be necessary to reassess Adorno's demand for asceticism in advanced art. The current danger may not be "fetishism" at all, but rather the troublesome consequences of fetishism's decline.

\section{The Marxian Fetish of Commodity Alienation}

According to Marx, a laborer's product becomes a commodity when produced for the purpose of exchange rather than direct use. He compares the commodity to a religious fetish because "the productions of the human brain appear as independent beings endowed with life, entering into relation both with one another and the human race."1 However, this is not simply an illusion. Marx claims the commodity's fetishistic appearance is both true and false: "the relations connecting the labor of one individual with that of the rest appear, not as direct social relations between individuals at work, but as what they really are, material relations between persons and social relations between things" (emphasis mine). ${ }^{2}$ Given the private production of capitalism, it is true that laborers relate to one another indirectly through the exchange of material goods. Their social relations are material relations. The workers' alienation from the commodity-its seeming lack of direct relation to their labortruthfully reflects the workers' alienation from one another.

At the same time, commodity fetishism is illusive because this impoverished social relationship between laborers is attributed to commodities: "a definite social relation between men, assumes, in their eyes, the fantastic form of a relation between things." The concrete labor-relations of humans, the very source of commodities and their value, go unnoticed in the commodity's abstract exchange-value. Because the link of the commodity's exchangeability to actual human activity is shrouded, "the process of production has the mastery over man, instead of being controlled by him." "The illusion is not this mastery (just as it is not illusory that the religious fetishist is subservient to the fetish-god); what is illusory is the implication that such a state of affairs is a "self-evident necessity imposed by nature." The commodity, seemingly disconnected from the worker's activity, takes on the character of external necessity or independent law; its existence and value appear to fall outside the realm of human control. Consequently, the fetishistic commodity falsely implies the impossibility of social change.

\section{The Freudian Fetish: The Fantasy of Reconciliation}

The Freudian theory of fetishism emphasizes, not alienation, but the illusion of a relation. Freud traces the origins of sexual fetishism to the castration complex. He claims 
that a young boy, upon discovering that women do not possess a penis, interprets this fact as a verification of the threat of castration. In order to preserve his relation of desire to the mother without endangering his own body, he must reject this lack: "The fetish is a substitute for the woman's (mother's) penis that the little boy once believed in and ... does not want to give up." The fetish is substituted for the mother's penis, Freud tells us, "to preserve it from extinction."

As in Marx's view, fetishism is related to a substitution. Here the fetish is substituted for the "maternal phallus," rather than exchange-value substituting for the social relations of labor. ${ }^{8}$ But while in Marx this substitution causes a loss of social relation to the object and to others (the commodity's autonomous, alienated character), in Freud the substitute seemingly prevents the loss of a social relation (prevents alienation from the opposite gender). Marx explains his use of the term "fetishism" by emphasizing the divorce of the object from the subject (the fetish-god's independence). Freud, on the other hand, emphasizes the subject's belief that the fetish overcomes this divorce. "Such substitutes," he says, "are with some justice likened to the fetishes in which savages believe that their gods are embodied" (my emphasis). ${ }^{9}$

Marx and Freud do agree in their analyses of the objective social situation of fetishism. In both cases, false relations substitute for authentic ones. They are "false" because they involve the loss of authentic satisfaction in social relationships. The commodity relationship of laborers is an impoverished material relation between subjects, rather than an authentic social relation. The relation of the Freudian fetishist to the fetish is also a degraded one; the fetishist's desire is directed toward an object-a thing without direct relation to his desire. In Marx, the alienating social relationships of capitalism substitute for authentic society, and in Freud submission to an object substitutes for the authentic sexual aim of an erotic bond to a human subject. ${ }^{10}$

The difference between the two theories lies in the subjective conditions-in the fetishistic subjects' perception of their own situation. In Marx, the producers encounter the substitute of the commodity as alienated and without relation to them. They see in the object their own loss of social satisfaction. The danger is not this substitution, which reveals their social privation. It is instead the commodity's independence, which convinces the subjects that the loss cannot be remedied, that commodity relations are the only possible human relation. In Freud, on the contrary, the subject is unaware of alienation or loss because he has transferred his desire from the mother to the fetish. Far from alienating him, the object reassures him that the desired relation has been achieved. Rather than despairing of alternatives, he simply does not recognize the need for any. The danger is heightened because he ignores his privation.

The Marxian and Freudian theories of fetishism analyze two different ways in which subjects can react to the loss of social relation. Because my principal concern is the defensive attitude taken by the subject toward the condition of social deprivation, rather than that condition itself, I will reserve the term "fetishism" for the Freudian theory, and "alienation" for the Marxian one. In the Freudian sense, there is nothing fetishistic about Marxian commodity alienation. Marx's producer is aware of alienation and resigns, in the face of the commodity's illusory authority, to the loss of social happiness. Freudian fetishism, on the contrary, is not resignation toward a dissatisfying substitute form of society. It is instead a substitute satisfaction, or false reconciliation.

\section{Benjamin and the Theory of Aura}

Benjamin's notion of "aura" corresponds to the substitute social relation of the fetish,

\section{PHILOSOPHY TODAY}


and not to Marxian commodity alienation. According to Benjamin, the auratic work of art is an object appearing as a subject: "Experience of the aura rests on the transposition of a response common in human relationships to the relationship between the inanimate or natural object and man." " As in fetishism, the aura of an object is its ability to substitute for a subject in the social relation. Unlike Marx's alienated commodities, which seem to have relations only with one another while being divorced from the subject and her labor, in the auratic object the subject recognizes herself, seeing humanity rather than a mere thing: "to perceive the aura of an object we look at means to invest it with the ability to look at us in return." ${ }^{\prime 2}$

As with fetishism, the relation to the object disguises an impoverished social relation between subjects. On one hand, both the fetish and the auratic object distance human beings from one other. Aura, Benjamin says, is essentially an experience of distance, and "the essentially distant is the inapproachable." ${ }^{, 13}$ On the other hand, however, the subject's distance from other subjects is disguised by the unique presence and authenticity of the object. ${ }^{14}$ Just as the Freudian fetishist believes he has achieved satisfaction in the presence of the fetish, the subject in the presence of the auratic artwork believes she has entered into a relation with lost social human experience: "the authenticity of a thing is the essence of all that is transmissible from its beginning, ranging from its substantive duration to its testimony to the history which it has experienced." ${ }^{\text {, }}$

The auratic object appears, then, as an exception to the commodity. Rather than cloaking its history of production, use, and exchange - that is, its connection to human life-under the abstract quantity of exchange-value, it wears its history on its sleeve. Its value is inseparable from its past concrete relations to subjects. Like the fetish, aura is distance and alienation in the guise of proximity and humanity. It is not alienation but false reconciliation.

\section{Adorno and the Fetish of Exchange-Value}

As in Benjamin's case, Adorno's analysis of fetishism in cultural goods has more in common with Freudian fetishism than Marxian commodity alienation. According to Adorno, commodity fetishism is the consumption of exchange-value under the guise of use-value:

If the commodity in general combines exchange-value and use-value, then the pure use-value, whose illusion the cultural goods must preserve in completely capitalist society, must be replaced by pure exchange-value, which deceptively takes over the function of use-value. ... The feelings which go to the exchange value create the appearance of immediacy at the same time as the absence of a relation to the object belies it. ${ }^{16}$ (my emphasis)

The exchange-value of the commodity is the fetishistic substitute for the satisfaction one desires from the product's qualitative use-value. The consumer has replaced the object of desire with the desire to exchange. As in sexual fetishism, where the fetish object replaces the sexual aim (means replaces end), the commodity is desired qua exchangeable (the means) rather than as use-value (the end). Adorno even borrows Freudian terminology to describe the phenomenon: "as a result of the displacement of feelings into exchange-value, no demands are really advanced in music anymore. Substitutes satisfy their purpose, because the demand to which they adjust themselves has itself already been substituted." (emphasis added). ${ }^{17}$

The crucial difference between Marxian alienation and Adorno's Freudian use of "fetishism" is the subject's perception of her situation. In Marx, the subject recognizes in the commodity a real inadequacy in her social condition. Relations appear "as they really are, material relations between persons and

ADORNO AND BENJAMIN 
social relations between things."18 In Adorno, on the contrary, this element of truth is clouded; the commodity becomes illusory through and through. The subject sees nothing lacking in the commodity or in her relationship to it. As with Benjamin's auratic object, exchange-value - the alienation of producers from their products - takes on the disguise of relation. However, for Adorno, the substitute is no longer an auratic connection to historical use, but the illusion of a present and immediate utility-a direct qualitative relation to the object.

Both Benjamin's aura and Adorno's commodity fetishism are defensive strategies against Marxian alienation, since both falsely suggest authentic social satisfaction achieved in relation to an object. However, Benjamin's aura still includes nostalgia for a relation to tradition and human experience, i.e., for a social relation to other subjects via the object, whereas Adorno's consumer gives up the other subject entirely, imagining full satisfaction in the object alone, in its appearance as pure use-value. ${ }^{19}$

\section{Benjamin's Diagnosis of Aura's Decline}

In both Benjamin and Adorno's positions, the danger is the subject's ignorance of actual privation. If fetishism were a final state of affairs, the outlook for social change would be grim, since the need for change would go unrecognized. However, Benjamin has given us reason to believe fetishism is not, in fact, the end of the matter. His claim of a "disintegration of the aura" implies a decline of fetishism. ${ }^{20}$

According to Benjamin, mechanical reproduction destroys the distance that maintains aura. Because the reproduced object is easily and inexpensively possessed, it incites and satisfies "the desire of contemporary masses to bring things 'closer' spatially and humanly ... to get hold of an object at very close range by way of its likeness, its reproduction." ${ }^{21}$ This might, at first glance, appear to reinforce fetishism. After all, it is characteristic of fetishism to seek to obtain satisfaction by possessing a substitute. And indeed, this desire to abolish distance is motivated by auratic fetishism. However, it is also fetishism's self-defeat.

The changes that come with the object's immediate availability destroy precisely that character that made the object function as a substitute. The nostalgic illusion of a connection to social experience is upheld by the auratic object's historical and unique character. It comforts by showing a seemingly human face. With the advance of mechanical reproduction, however, the human qualities of the commodity dissolve. Because reproduced commodities are flawless, new, and identical-lacking uniqueness or history"the technique of reproduction detaches the reproduced object from the domain of tradition. ${ }^{22}$ The object is brought too close for its magic - the appearance of humanness and sociability - to be preserved. The fetish is appropriated only to become an empty commodity without relation to human experience.

The consequence of this decline is an authentically Marxian form of alienation. According to Benjamin, the auratic object's conversion to commodity takes the form of and "experience of shock." 23 The object's proximity, coupled with its absence of connection to the human, is experienced as pain - as the constant threat of danger. Benjamin's favorite analogy for this experience is big city traffic: "Moving through this traffic involves the individual in a series of shocks and collisions. At dangerous intersections, nervous impulses flow through him in rapid succession, like the energy from a battery." ${ }^{24}$ The comforting traces of past social experience that had relieved the social situation begin to disappear. The subject has not voluntarily given up fetishism; objective conditions have made such evasive strategies increasingly difficult. What once, as aura, returned the human gaze, now confronts the

\section{PHILOSOPHY TODAY}


subject as blind physical force or sheer stimulus.

\section{Freudian Identification and Repetition: Reconciliation Without Fetishism}

Benjamin's analysis of aura's decline and conversion to shock introduces a non-fetishistic subjective response to alienation. This alternative to fetishism is drawn explicitly from Freud's theory of traumatic neurosis in Beyond the Pleasure Principle. ${ }^{25}$ Freud claims that victims of war trauma repeatedly dream about their traumatic experiences in order to overcome shock: "these dreams are endeavouring to master the stimulus retrospectively, by developing the anxiety whose omission was the cause of the traumatic neurosis.. ${ }^{26}$ In a similar way, the subject's experience of shock in the alienated commodity is countered in two ways: 1) by habituating to shock through its repetition, and 2) by identifying with the active agent that produced the shock.

According to Benjamin, modern cultural products serve as preparation for the safe reception and ultimate mastery of shock: "technology has subjected the human sensorium to a complex kind of training. There came a day when a new and urgent need for stimuli was met by the film. ${ }^{, 27} \mathrm{He}$ compares this trained reception of shock to tactile, as opposed to visual and contemplative, appropriation:

This mode of appropriation, developed with reference to architecture, in certain circumstances acquires canonical value. For the tasks which face the human apparatus of perception at the turning points of history cannot be solved by optical means, that is, by contemplation alone. They are mastered by habit, under the guidance of tactile appropriation. ${ }^{28}$

The consequence of this curious training is a new kind of artistic reception:
The painting invites the spectator to contemplation; before it the spectator can abandon himself to his associations. Before the movie frame he cannot do so. No sooner has his eye grasped a scene than it is already changed. It cannot be arrested. ... . This constitutes the shock effect of the film, which like all shocks, should be cushioned by heightened presence of mind. ${ }^{29}$ (my emphases)

Benjamin misleadingly calls this behavior "reception in a state of distraction., ${ }^{, 30}$ But distraction is not, in his sense, a state of unconsciousness or a lack of perception. On the contrary, it is closer to attention, alertness, or being on guard. It is called "distraction" because one is constantly attending to changes of scene, disruptions, and disconnections that make immersed contemplation impossible. Habituation to such disruptions allows one to experience shock effects without being harmed by them. By anticipating shock, one is ready for it and immune to it. One becomes impervious-a "shock absorber" of sorts. Such reception includes both attention and distraction in the same way that the Freudian trauma patient is dreaming and preoccupied, although alert to the source of her suffering.

"Reception in a state of distraction" is, in fact, the precondition of non-fetishistic reception. Through habit, the subject develops the capacity to withstand alienation and displeasure. This is contrary to fetishistic reception, in which the threatening perception of alienation is evaded through false reconciliation in the fetish substitute. In non-fetishistic "distraction" one is distracted by and attentive to the shock of privation. One acknowledges precisely those elements of the social condition that fetishism ignores-the comfortless tactile stimuli that "hit the spectator like a bullet," ${ }^{\prime 31}$ the collisions of the crowd, street and factory, and the sudden disruptions of scene or camera angle that defy the 
fetishistic illusion of human, auratic experience.

One is distracted from, on the other hand, precisely the auratic and fetishistic substitutes that disavow, cover, or draw attention away from shock. "The film," Benjamin claims, "makes the cult value recede into the background." 32 The subject is distracted from the harmonic image of the auratic that allows for comfortable contemplation, from the illusion that makes her incapable of tolerating what belies aura. As Benjamin puts it, "the man who concentrates before a work of art is absorbed by it. . . . In contrast, the distracted mass absorbs the work of art. ${ }^{{ }^{\prime 3} 3}$ To concentrate upon and be absorbed by a work requires that the work be non-threatening; it must have the fetishistic quality of an object become human, returning and reassuring one's gaze. A work that distracts, on the contrary, defies this fetishistic pseudo-relation. Its shock constantly reinforces the division between the subject and the commodity.

This acknowledgement and mastery of privation is the precondition of the move from passivity to activity. We have seen that, for Marx, the alienated subject believes she is powerless before the independent laws of the commodity. However, the subject's repeated exposure and habituation to alienation is the objective possibility of reconciliation. In this way the subject overcomes submissiveness to, and fear of, the alienated commodity. In the training of repeated shocks she subjects herself to the object, rather than being subjected to the object. She is training for the assumption of an active role.

Once again, Benjamin has drawn heavily from Freud's Beyond the Pleasure Principle. There Freud describes a game in which a young boy throws a toy away from him with a cry of "fort" ("gone"), and retrieves it again with a cry of " $d a$ " ("there"). Freud interprets the game as a reenactment of the mother's temporary departure and return. It is, he says,

\section{PHILOSOPHY TODAY}

related to the child's great cultural achievement-the instinctual renunciation ... . which he had made in allowing his mother to go away without protesting. ... At the outset he was in a passive situation-he was overpowered by the experience; but, by repeating it, unpleasurable though it was, as a game, he took on an active part. ${ }^{34}$

The child not only tolerates the loss, but also causes it to occur again in the game. He identifies with the mother's role. It is now the child that takes leave, not the mother. By making this identification, he anticipates his move from the passive demand for immediate satisfaction under the pleasure principle to the toleration of privation under the reality principle. Such toleration is essential if the child is to recognize the reality of his privation and eventually, through activity, modify the reality that causes his displeasure.

The contrast to fetishism is striking. The fetishist refuses to acknowledge shock, and thus maintains the illusion that no change in social condition is required. The pleasure principle, passivity, and immediate gratification determine the fetishist's actions. Repetition of shock and identification are, on the contrary, an anticipation of the reality principle, self-command, and the modification of the real. In Freudian theory, it is precisely such a strategy that will allow a child to resolve the Oedipus complex without resorting to the evasive strategy of fetishism. Whereas the fetishist preserves the prohibited desire by finding a substitute object, the "normal" child will identify with the father and reenact the father's prohibition actively, rather than be subjected to it: "the child's parents, and especially his father, were perceived as the obstacle to a realization of his Oedipus wishes; so his infantile ego fortified itself for the carrying out of the repression by erecting this same obstacle within itself., ${ }^{35}$

In Benjamin's analysis, this identification involves positioning oneself, not as passive recipient or audience member, but rather as 
author, camera, or critic: "the audience's identification with the actor is really an identification with the camera. Consequently the audience takes the position of the camera; its approach is that of testing. ${ }^{, 36}$ Benjamin even suggests that every audience member becomes "somewhat of an expert.", ${ }^{37}$ For our purposes, the audience's true status as expert is not crucial. What is crucial is that by both recognizing its alienation and identifying with the agent of its alienation (the producers of the commodity), the audience is preparing for the activities of judgment, production, and modification of commodities.

Two important conclusions can be drawn. First, the repetition of shock makes the fetishistic evasion of shock unnecessary. Second, imaginative identification with agency is preparatory to the overcoming of Marxian alienation. It is, to be sure, only an imaginary step. Identification is not authentic agency. Nevertheless, imagined agency truthfully suggests the possibility of a changed relation to the commodity. The subject has, to some degree, recognized her potential to act of her own accord, rather than in obedience to an actual, but historically conditioned, state of affairs.

\section{Resistance to Fetishism in Adorno's Analysis of "Regressive Listening"}

Like Benjamin, Adorno acknowledges the presence of alienation, shock, and displeasure in the relation of the subject to the commodity. He calls the reception of the alienated commodity "regressive listening":

Regressive listening appears as soon as advertising turns to terror, as soon as nothing is left for the consciousness but to capitulate before the superior power of the advertised stuff and purchase spiritual peace by making the imposed goods literally its own thing. In regressive listening, advertising takes on a compulsory character. ${ }^{38}$ (my emphasis)
Like Benjamin, he claims that the subject's reception of the shock of alienation involves identification. However, contrary to Benjamin, Adorno claims the subject identifies with the commodity itself, not with the commodity's producer:

They overcome the feeling of impotence that creeps over them in the face of monopolistic production by identifying themselves with the inescapable product. They thereby put an end to the strangeness of the musical brands which are at once distant from them and threateningly near. ${ }^{39}$ (my emphasis)

While Benjamin believes that the reception of shock distracts the subject from auratic or fetishistic qualities, Adorno insists that "regressive listening" supports the continued success of fetishism, even given the decline of aura. The subject can fetishistically identify with the commodity-that is, continue to see in it a relation to the human-because she mistakes exchange-value (the commodity's being-for-exchange) for use-value (its being-for-human use). However, Adorno's own analysis provides reasons to reject this claim. The regression of listening is not, as he says, a "counterpart to the fetishism of music." ${ }^{40}$ It is, instead, at odds with fetishism.

According to Adorno, regressive listening is the rejection from consciousness of difference-of anything that defies commodification or exposes alternatives to it:

Whenever they have the chance, they display the pinched hatred of those who really sense the other but exclude it in order to live in peace, and who therefore would like best to root out the nagging possibility. The regression is really from this existent possibility, or more concretely from the possibility of a different and oppositional music. $^{41}$

ADORNO AND BENJAMIN 
He even explicitly characterizes regressive listening as a neurosis:

There is actually a neurotic mechanism of stupidity in listening too; the arrogantly ignorant rejection of everything unfamiliar is its sure sign. Regressive listeners behave like children. Again and again, and with stubborn malice, they demand the one dish they have been served. ${ }^{42}$

In regressive listening, as in both neurosis and psychosis, something is prevented from reaching consciousness. ${ }^{43}$ However, this disavowal of alternatives is inconsistent with fetishism. The very motivation of fetishism is to preserve a sexual relation without resorting to either repression of instinct or the disavowal of external reality. ${ }^{44}$ The sexual fetishist fully believes that it is the fetish he wants, and nothing else. Consequently he has no need to deny the reality of an alternative to the fetish. ${ }^{45}$

In Adorno's theory, the substitution of exchange-value for use-value accomplishes the same. Alternatives to the fetishistic satisfaction of the commodity pose no threat to the fetishist, and need not be rejected by consciousness. Although both the disavowal of external reality and fetishism counteract the temptation to indulge in a prohibited satisfaction, they do so in entirely different ways. The disavowal of alternative satisfaction makes fetishism unnecessary (because one cannot be tempted by unperceived alternatives), and fetishism makes disavowal unnecessary (because one no longer desires the alternatives). If it were true, as Adorno claims, that the subject has fetishistically identified with the commodity, then the refusal to be conscious of alternatives would be superfluous.

But disavowal of alternatives is not simply inconsistent with fetishism; it is incompatible with fetishism. According to Adorno, the fetishist believes pleasure in the exchange-value of the commodity is actually pleasure taken in the qualitative use-value of the product. That is, the fetishist is unaware of a distinction between product enjoyed qua commodity or enjoyed qua use-value. Because this distinction is not recognized, any pleasure incidentally occasioned by use-value will not be distinguished from the substitute pleasure taken in exchange-value. The fetishist may be conscious of the alternative (she may experience non-fetishistic pleasure), but she will not be conscious of it as an alternative. To use an example of Adorno's, a fetishistic concertgoer will not see any difference between enjoyment in the price of a concert ticket and enjoyment in the music performed. ${ }^{46}$ Fetishism only succeeds because the fetishist does not distinguish authentic from false satisfactions.

Because regressive listeners compulsively disavow alternatives to the fetishistic commodity, then they must, unlike the fetishist, be capable of distinguishing the fetishistic from the non-fetishistic, exchange-value from use-value. After all, the alternatives cannot be rejected unless recognized as alternatives. The listener excludes difference "in order to live in peace" and "root out the nagging possibility." ${ }^{47}$ But difference can only pose a threat to the listener's peace provided she is able to recognize it as a desirable alternative-precisely what the fetishist does not recognize. Consequently, the regressive listener's relation to the commodity cannot be one of fetishistic pleasure in a substitute. It is, rather, one of resignation toward acknowledged privation.

Such resignation in the face of commodity alienation is characteristic of Marx's analysis, and antagonistic to the fetishism described by Freud and Adorno. Furthermore, the consumers' compulsive return to the alienated commodity is characteristic of Benjamin and Freud's descriptions of non-fetishistic shock training. So Adorno's notion of disavowal in regressive listening demonstrates, against his intentions, that fetishistic identification with commodities is

\section{PHILOSOPHY TODAY}


becoming increasingly unsuccessful - just as Benjamin has claimed.

\section{The Critique of Non-Fetishistic Reconciliation: Pathological Realism}

Advancements in commodity production lead to the decline of auratic fetishism. Given the necessity of disavowal in regressive listening, a similar decline must occur in the case of exchange-value fetishism. Adorno has even provided an excellent explanation of the phenomenon. Commodity fetishism leads to a condition in which "in broad areas the same thing is offered to everybody by the standardized production of consumption goods. ${ }^{, 48}$ With increased standardization, it becomes increasingly difficult for exchange-value to take the disguise of use-value; the difference between the two becomes too glaring to support the fetishistic substitution. ${ }^{49}$ Adorno mentions, for example, mass music's "standardized products," which "do not permit concentrated listening without becoming unbearable to the listeners." ${ }^{50}$ And he admits: "even the most insensitive hit song enthusiast cannot always escape the feeling that the child with a sweet tooth comes to know in the candy store.... Nobody believes so completely in prescribed pleasure." 51

Given a decline in both fetishistic aura and the fetishism of exchange-value, it would seem that the problem has evaporated. But we still have to contend with Marxian commodity alienation. The crucial element of Marx's analysis is the illusion of necessity and helplessness. Although no longer a fetishist in Freud or Adorno's sense, the regressive listener still considers her condition irreparable. She recognizes her alienation in the commodity, but feels powerless to alter it. The only defense against alienation that apparently remains is the disavowal of alternatives. Because such alternatives appear to the alienated consumer as merely exceptions to the rule, lacking the commodity's authoritative power, their difference can only aggra- vate dissatisfaction with the ubiquitous commodity. Again, Adorno has provided an excellent explanation:

It suffices to remember how many sorrows he is spared who no longer thinks too many thoughts, how much more "in accordance with reality" a person behaves when he affirms that the real is right, how much more capacity to use the machinery falls to the person who integrates himself uncomplainingly, so that the correspondence between the listener's consciousness and the fetishized music would still remain comprehensible even if the former did not unequivocally reduce itself to the latter. ${ }^{52}$

It is not, then, necessary for the subject to buy into fetishism to be passive to the commodity. Though the regressive listener recognizes the inadequacy of the commodified product, her recognition of a real state of affairs (the primacy of the commodity over the subject) leads her to the conclusion-to some extent correct-that alternatives will increase, not remedy, her dissatisfaction. However, the subject's resignation is only partly "in accordance with reality." It may be true that producers are subservient to production, but they are not necessarily so. It may also be true that a product that defies commodification is powerless and doomed to extinction - but only given Marxian alienation, which is not an objectively necessary state of affairs. ${ }^{53}$

Regressive listening is not fetishistic substitute pleasure, but instead a paradoxicalperhaps even pathological-adherence to the reality principle. Or rather, it is the reality principle turned against itself. The subject is so energetically committed to the recognition of real privation (and thus to the rejection of fetishism) that she rejects as fantasy anything in the real that defies the general state of affairs. In her commitment to the reality principle, she disavows possibility. Rather than recognize that alternative products are evidence of the real power of pro-

ADORNO AND BENJAMIN 
ducers over the commodity, the subject sees them only as accidents or anomalies. She attributes their existence (like that of the commodity in general) not to the agency of the producer and consumer, but to the whims of exchange and market. This pathological form of realism, far from fetishistically confusing alienation with satisfaction, resolutely accepts privation as such. It is not the illusion of satisfaction, but despair over the possibility of alternatives. Any suggestion of the possibility of value beyond exchange is pathologically labeled pathology.

This "pathological realism" in regressive listening provides the basis for a critique of Benjamin's optimistic theory of repetition-identification. The source of his optimism is the subject's identification with agency. By identifying with the producer, the alienated subject anticipates the ability to take control of the commodity and modify the condition of privation. Privation is tolerated only to bring about its end. But this is a dangerous strategy. The Freudian "introjection" of the father as superego is identification with the father, not only as agent, but also as the voice of prohibition.

In Freudian theory, the child's instinctual privation is necessary due to its dependence upon its parents. However, through identification this objective condition becomes a subjective one-the father's prohibition and authority is moved from a perceived state of reality to an internal psychical system. Although this objective condition changes when the child becomes an independent adult, the superego's prohibition does not. Consequently, a conditional state of reality is given illusive permanence through its introjection. If the identification is too successful, the child will not ultimately modify the real to allow for satisfaction, but instead simply take over the father's job of prohibition, reinforcing the condition of privation. Freud, unlike Benjamin, is careful to emphasize this danger:

\section{PHILOSOPHY TODAY}

The more powerful the Oedipus complex was and the more rapidly it succumbed to repression (under the influence of authority, religious teaching, schooling and reading) the stricter will be the domination of the super-ego over the ego later on-in the form of conscience or perhaps of an unconscious sense of guilt. ${ }^{54}$

The super-ego retained essential features of the introjected persons - their strength, their severity, their inclination to supervise and to punish. As I have said elsewhere, it is easily conceivable that, thanks to the diffusion of instinct that occurs along with this introduction into the ego, the severity was increased. The super-ego-the conscience at work in the ego-may then become harsh, cruel and inexorable against the ego which is in its charge. ${ }^{55}$

Adorno's description of regressive listening fits Freud's analysis of the excessively severe super-ego. The regressive listener's refusal to recognize alternative qualities in the commodity (and thus the possibility of alternative forms of production) is a compulsive obedience to historical authority at the expense of the reality principle. As we saw in Benjamin's theory, when the audience masters the shock of the commodity, the possibility of controlling commodities becomes objectively real. However, because consumers have identified with the self-prohibitive character of the alienated producer and not with a truly active producer, they compulsively reject this possibility. Their eventual activity, rather than being a rejection of alienated production, is a repetition of it. Adorno labels this "pseudo-activity," or "the imitative assimilation to commodity models." 56

If, as Freud claims, the super-ego takes on the character of the models with which the subject has identified, then Adorno is right to criticize Benjamin's theory of distracted listening. Although the audience is distracted from the auratic qualities of the commodity, 
fetishism is no longer the problem. Distraction from fetishistic aura is also, like "regressive listening," a distraction from exceptions and alternatives to the alienated commodity. If the subject attends only to shock, and not to the possibility of its removal, then identification with the producer is training in self-betrayal. Benjaminian "expertise" prepares the subject for the expert reproduction of the condition of alienation:

The new listeners resemble mechanics who are simultaneously specialized and capable of supplying their special skills to unexpected places. ... The more easily they meet the demands of the day, the more rigidly they are subordinated to that system. $^{57}$

\section{Conclusion}

Benjamin has, against Adorno, correctly diagnosed a decline in Freudian-style fetishism, a decline evidenced by the necessity of the non-fetishistic strategy of disavowal of alternatives. However, he is mistaken to imply that the decline of aura involves a decline in the Marxian version of commodity fetishism. The distracted audience's identification with the expert or author does not break down the illusion of the alienated commodity's authority. On the contrary, it may be the active acceptance and reinforcement of that authority. Benjamin's audience members develop a tolerance for shock and recognize the product's dependence upon the producer. But this is not sufficient to cause a decline in Marxian fetishism. They must also recognize the producer's possible independence from the dominant mode of productionthat is, the producer's ability to produce in a new way.

Given Benjamin's theory, such recognition is unlikely for two reasons. First, the audience's practiced ability to endure shock and expert knowledge of current commodities significantly reduces the motivation to transform production. Once the subject has become accustomed to the alienated commodity, it is easier to adapt to the current forms of production rather than to transform them. Second, distracted listening involves attention to shock or danger and distraction from the illusory aura of social relation. Because the subject's real condition is alienation, it is only in the auratic qualities of artworks or products that she can encounter the possibility of an alternative. The auratic is illusory as a seemingly present social relation, but not in its implication of the objective possibility of such a condition. While Benjamin is quite aware of this element of truth in the auratic, ${ }^{58}$ his own theories of distracted reception and the decline of aura suggest that the truth of the auratic is likely to go unnoticed by the subject.

Adorno, on the contrary, is painfully aware of this difficulty. He wisely rejects the notion that repetitive-identification with commodity models will lead to the overcoming of Marxian alienation. And he correctly points out that the changes in reception noted by Benjamin are in accordance with the authority of the alienated commodity and tend to preserve Marxian alienation. However, he mistakenly believes that regressive listening includes and supports fetishism in the Freudian sense, leading him to reject Benjamin's theory of a decline of fetishism.

Adorno's mistaken view of contemporary reception has troublesome consequences for his demands upon contemporary artwork. The danger of the contemporary situation is not fetishism, but what I have called the "pathological realism" of regressive listening. The danger of distracted or regressive reception is that the preparation for an active relation to production involves repeated encounters with alienating products and identification with alienated producers. The lack of attention to products that resist alienation is also an incapacity to recognize the possibility of alternative products and forms of production. Trained in the alienated production of alienating commodities, the subject's potential activity is likely to maintain the 
condition of social privation. If Marxian alienation can be overcome, it can only be by the audience's repeated exposure to exceptions to alienated production. In Freudian language, they must form their "super-egos" by identification with the producers of alternative cultural products.

However, Adorno's demands upon contemporary artwork imply precisely the opposite. He claims that regressive listeners receive artworks in a vulgarized way-as a collection of isolated, culinary moments rather than as a synthesis of those moments. In its reception, the artwork becomes one commodity among others:

No longer do the partial moments serve as a critique of the whole; instead they suspend the critique which the successful esthetic totality exerts against the flawed one of society. ... They [isolated moments of enjoyment] are not bad in themselves but in their diversionary function. In the service of success they renounce that insubordinate character which was theirs. ${ }^{59}$

On Adorno's view, this conversion of the artwork into commodity is fetishistic; immediate pleasure in isolated, enjoyable moments enhances the illusion of achieved satisfaction and obviates the need for social change (as well as the need to attend to the work as a whole).

I have argued, on the contrary, that regressive listening is not fetishistic. If regressive listeners are diverted by the isolated moments of the work, it is not because the moments provide substitute gratification, but because (as Adorno has himself claimed) an artwork as a whole presents an alternative to the commodity, and threatens the listeners' complaisance to alienation. Consequently, the conversion in listening of the artwork into commodity simply means that the listeners have missed the work's critique, not that they have undermined it by finding fetishistic satisfaction in it. The audience either does not find anything at all or receives the artwork as identical to any other commodity - that is, as a tolerated privation of full satisfaction. If this is correct, then the vulgarization of the artwork in listening does not encourage fetishistic illusion. Admittedly, the artwork will have little critical impact on the audience, but it will not, at least, have a negative one. The individual "moments" of the artwork lose their once "insubordinate character," but they do not "conspire against freedom." ${ }^{\circ 0}$ They become innocuous, not pernicious.

Adorno's conviction that the partial moments of the artwork have pernicious effects grounds his demand for an advanced, "ascetic" form of artwork that "has renounced consumption." ${ }^{\text {"1 }}$ The traitorous "moments of enjoyment" (he also calls them moments of gaiety, impulse, sensuality, charm, etc.- - see 272-74) must be eliminated from the artwork. This demand changes the entire nature of the artwork's critique. Originally, the synthesis of these subjective moments in the unified work presented "the image of a social condition in which above those particular moments of happiness would be more than mere appearance., ${ }^{, 2}$ But when the moments of happiness are excised, the image of possible social reconciliation is lost. The advanced work of art instead "records negatively" the possibility of happiness: "the promise of happiness, once the definition of art, can no longer be found except where the mask has been torn from the countenance of false happiness. ${ }^{\circ 3}$ The ascetic work of art provides a non-fetishistic image of our real condition rather than a hopeful image of possible alternatives to that condition.

However, Adorno has repeated Benjamin's mistake. Both thinkers seek to overcome the fetishistic illusion of happiness, a danger that is already in decline. As we have seen in our criticism of Benjamin's theory, the danger is precisely the opposite - the despair of the possibility of happiness. What is needed in order to bring about reconciliation is the presentation of alterna-

\section{PHILOSOPHY TODAY}


tive satisfaction-precisely what Adorno has forbidden in art. The ascetic artwork that Adorno endorses tells the subject precisely what she already knows too well: that the current condition is one of alienation and dissatisfaction. More importantly, the ascetic work reinforces the regressive listener's belief that the current condition is the only possible one. The listener's despair is grounded in the faithful perception of real conditions. If artistic asceticism decreases the number of exceptions to alienation encountered in the real, then the true dangerthe illusion of alienation's necessity-will be reinforced. By renouncing the presentation of possible happiness, the artwork despairs both of its own possibility and that of its audience. It may be true that regressive listeners are currently incapable of receiving an artwork as a synthesized whole, but Adorno's demands would ensure that they remain incapable of doing so. Ironically, Adorno's ascetic artwork is precisely what the "pseudo-activity" of Benjamin's "expert" is accused of being - the dutiful reproduction of alienation without any intimation of alternate possibility.

\section{ENDNOTES}

1. Karl Marx, Capital: A Critique of Political Economy, trans. Samuel Moore and Edward Aveling (New York: The Modern Library/Charles H. Kerr and Company, 1906), p. 83.

2. Ibid., p. 84.

3. Ibid., p. 83 .

4. Ibid., p. 93.

5. Ibid.

6. Sigmund Freud, "Fetishism," in The Standard Edition of the Complete Psychological Works of Sigmund Freud, trans. James Strachey, (London: Vintage/Random House, 2001), 21:152-53.

7. Ibid.

8. Note that the child's interest in the fantasized maternal phallus is not, according to Freud, an interest in a body-part qua object. The fetishist preserves the maternal phallus only because it refutes the father's threat of castration, and not because he desires an object rather than a subject. Its existence is necessary in order for the child to defy the prohibition of incest; it represents the safety, and hence the possibility, of an authentic relation to another subject.

9. Freud, Three Essays on the Theory of Sexuality, in The Standard Edition, 7:153.

10. It should be emphasized that Freud does not distinguish deviations from heterosexuality in normative terms. However, he does consider "pathologi- cal" those forms of sexuality which (as can be the case in fetishism) renounce the instinctual aim of the removal of the organic stimulus of the instinct-i.e., the renunciation of sexual satisfaction (ibid., pp. 154 and 161). The analogy to Marxian alienation holds for both pathological and non-pathological forms of Freudian fetishism, since in both cases a relation to an object replaces a relation to a subject.

11. Walter Benjamin, "On Some Motifs in Baudelaire," in Illuminations, ed. Hannah Arendt, trans. Harry Zohn (New York: Schocken Books, 1969), p. 188.

12. Ibid.

13. Ibid. See also Walter Benjamin, "The Work of Art in the Age of Mechanical Reproduction," in Illuminations, Section III, pp. 222-23.

14. Benjamin, "Work of Art," p. 220.

15. Ibid., 221.

16. Theodor W. Adorno, "On the Fetish Character in Music and the Regression of Listening," trans. Maurice Goldbloom, in The Essential Frankfurt School Reader, ed. Andrew Arato and Eike Gebhardt (New York: The Continuum Publishing Company, 1998), p. 279.

17. Ibid., 290. Compare Freud, "Splitting of the Ego in the Process of Defense," The Standard Edition, 23:277, "He [the fetishist] created a substitute for

ADORNO AND BENJAMIN 
the penis which he missed in females. ... He effected no more than a displacement of value."

18. Marx, Capital, p. 84.

19. The difference between the two can be compared to the Freudian distinction between non-pathological and pathological fetishism. In non-pathological fetishism, the aim of a sexual relation with the mother is not given up, but preserved through the fetish. The fetish as phallic substitute preserves the child's identification with the mother, and denies the threat of castration. By mediating his relationship to another subject with an object that represents her identity to and safety for his own body, he establishes a fantasized relation to that subject. In pathological fetishism, on the contrary, the sexual aim - and with it the desire for a sexual relation with another subject - is given up as inferior to the fetish. The fetish no longer mediates between the child and another subject, but instead becomes the sole object of desire. In both cases, the privation of authentic sexual satisfaction is not acknowledged.

20. Benjamin, "Baudelaire," p. 194.

21. Benjamin, "Work of Art," p. 223.

22. Ibid., p. 221.

23. Benjamin, "Baudelaire," p. 194.

24. Ibid., 175. See also "Work of Art," p. 250, note 19.

25. Benjamin, "Baudelaire," pp. 160-62.

26. Freud, Beyond the Pleasure Principle, in The Standard Edition, 18:31-32.

27. Benjamin, "Baudelaire," p. 175.

28. Benjamin, "Work of Art," p. 270.

29. Ibid., p. 238.

30. Ibid., p. 240.

31. Ibid., p. 238.

32. Ibid., p. 240.

33. Ibid., p. 239.

34. Freud, Beyond the Pleasure Principle, 18:15.

35. Freud, The Ego and the Id, in The Standard Edition, 19:34.

36. Benjamin, "Work of Art," pp. 228-29.

37. Ibid., p. 231.

38. Adorno, "On the Fetish Character in Music," p. 287.

39. Ibid., pp. 287-88.

40. Ibid., p. 286. See also p. 287: “Together with sport and film, mass music and the new listening help to make escape from the whole infantile milieu impossible. The sickness has a preservative function." And see pp. 291-92: “Their [regressive listeners'] revolts against fetishism only entangle them more deeply in it."

41. Ibid., p. 286.

42. Ibid., 290. See also pp. 286-87: "They are not merely turned away from more important music, but they are confirmed in their neurotic stupidity.the assent to hit songs and debased cultural goods belongs to the same complex of symptoms as do those faces of which one no longer knows whether the film has alienated them from reality or reality has alienated them from the film ..." (my emphasis).

43. See also Adorno, p. 278: "values are consumed and draw feelings to themselves, without their specific qualities being reached by the consciousness of the consumer," and p. 286: "the listening subjects lose, along with freedom of choice and responsibility, the capacity for conscious perception of music." This is actually more consistent with psychosis than neurosis. Freud describes the former as disavowal of an external reality, the latter as repression of an instinct ("Fetishism," p. 155). Nonetheless, in both cases, a threatening idea is withheld from consciousness.

44. Freud, "The Splitting of the Ego in the Process of Defence," The Standard Edition, 23:275-76, "Both of the parties to the dispute obtain their share: the instinct is allowed to retain its satisfaction and proper respect is shown to reality."

45. The sexual fetishist does not believe the castration threat, since the presence of the fetish prevents the seeming verification of that threat. Consequently, the fetishist does not believe that a non-fetishistic sexual relation with another subject is impossible, only that it is not desired. The alternative to fetishism is recognized, but devalued.

46. Adorno, "On the Fetish Character in Music," p. 278: "This is the real secret of success. It is the mere reflection of what one pays in the market for the product. The consumer is really worshipping the money that he himself has paid for the ticket to the Toscanini concert."

\section{PHILOSOPHY TODAY}


47. Ibid., p. 286.

48. Ibid., p. 280.

49. For example, two nearly identical commodities with drastically different exchange-values defy the fetishistic equation of exchange-value and use-value. A commodity fetishist would believe that the object of higher exchange-value is more satisfying, a belief made impossible by an extremely close qualitative similarity between the objects. In addition, the standardization of commodities makes the strategy of reconciliation through possession unnecessary. If a new commodity is identical to one already possessed-i.e., if it is overly familiar-it lacks the threat of alienation that motivates consumption. Without an aspect of "terror" (as Adorno describes it) or "shock" (as Benjamin puts it) there is no need to, in Adorno's words, “purchase spiritual peace by making the imposed goods literally [one's] own thing” (p. 287). In Benjamin's language, there is no need for shock training when commodities cease to shock. This results in indifference to new commodities through familiarity (Benjamin's "habit")—despite the fetishistic allure of their exchange-value.

50. Ibid., p. 288.

51. Ibid., p. 290.

52. Ibid., p. 286.

53. Compare ibid., p. 297: "But technically consistent, harmonious mass music purified of all the elements of bad pretense would turn into art music and at once lose its mass basis. All attempts at reconciliation, whether by market-oriented artists or collectively-oriented art educators, are fruitless." Such severely pessimistic conclusions in Adorno's essay bear strong traits of Marxian alienation, the illusion that the given exhausts the possibilities of the real.

54. Freud, The Ego and the Id, pp. 34-35.

55. Freud, "The Economic Problem of Masochism," The Standard Edition, 19:167.

56. Adorno, "On the Fetish Character in Music," p. 292.

57. Ibid., p. 294.

58. See, for example, "Paris, Capital of the Nineteenth Century," in Reflections (New York: Harvest/HBJ Books, 1979), 148: "In the dream in which, before the eyes of each epoch, that which is to follow appears in images, the latter appears wedded to elements from prehistory, that is, of a classless society. Intimations of this, deposited in the unconscious of the collective, mingle with the new to produce the utopia that has left its traces in thousands of configurations of life, from permanent buildings to fleeting fashions."

59. Adorno, "On the Fetish Character in Music," p. 273.

60. Ibid.

61. Ibid., p. 276.

62. Ibid., p. 273.

63. Ibid., p. 274.

\section{University of Toronto, Toronto, Ontario M5S 1A1, Canada}

